\title{
Binding Specificity of Antiidiotypic Autoantibodies to Anti-DNA Antibodies in Humans
}

Takeshi Sasaki, Tai Muryoi, Osamu Takai, Elichi Tamate, Hiroshi Saito, and Kaoru Yoshinaga

Department of Internal Medicine, Tohoku University School of Medicine, Sendai 980, Japan

\begin{abstract}
Human antiidiotypic antibodies to anti-DNA antibodies can be separated into at least two categories based on their binding to anti-DNA, antiidiotypic antibodies, and antigens. One type was found mainly in inactive stage of SLE. The antiidiotypic antibodies appear to be directed towards idiotype (Id) determinants in the antigen-binding sites of anti-DNA antibodies. Antibody from patient T.K. acted like a mirror image of antisingle-stranded DNA antibodies, 0-81, as determined by a competitive inhibition RIA. Antibodies from patient S.U. also seemed to be $A b 2 \beta$ and $A b 2 \gamma$ to anti-double-stranded(ds) DNA antibodies, NE-1. Most of normal subjects, on the other hand, had antibodies that bound to the human monoclonal anti-ds DNA antibodies, NE-1, NE-13, 7F4, and 0-81. The Id-anti-Id interaction was not inhibited by the addition of DNA. Thus, normal subjects had Ab2 $\alpha$ activity that recognizes Id determinants in the framework region common among antiDNA antibodies, whereas antiidiotypic antibodies in most SLE sera appear to show Ab $2 \beta$ and Ab $2 \gamma$ activity. The results provide evidence that the Id network system regulates immunological tolerance to DNA in humans.
\end{abstract}

\section{Introduction}

Antiidiotypic antibodies were originally described by Oudin and Michel (1) and Kunkel et al. (2), and now are well known to play an essential regulatory role in immune network systems (3-5). Idiotype(Id) immunity is thought to be an important mechanism for the maintenance of immunological tolerance to self-antigens and autoimmunity might be attributed to the disturbance of down-regulation of autoreactive clones in an Id network (6-8). Experimentally induced anti-Id antibodies have been shown to bind to Id determinants of autoantibodies (9-12). Most recognize a unique Id of autoantibodies, such as anti-DNA antibodies, antiacetylcholine receptor antibodies, antithyroglobulin antibodies or rheumatoid factor. However, some appear to be directed to Id determinants common to different kinds of autoantibodies $(13,14)$. Clinical investigations have revealed the presence of anti-Id autoantibodies to self-reacting antibodies in human (15-17). It is interesting that the Id of anti-DNA antibodies was found in active stage of systemic lupus erythematosus (SLE), whereas the

Address reprint requests to Dr. Sasaki, The Second Department of Internal Medicine, Tohoku University School of Medicine, Seiryocho 1-1, Sendai 980, Japan.

Received for publication 2 October 1987 and in revised form 11 January 1988.

J. Clin. Invest.

(C) The American Society for Clinical Investigation, Inc. 0021-9738/88/09/0748/07 \$2.00

Volume 82, September 1988, 748-754
anti-Id antibodies occur spontaneously in the inactive stage (15). Anti-Id antibodies act in immune system by recognizing the complementary Id on the surface of immune competent cells $(4,5,18)$. When administered in vivo, experimentally induced monoclonal anti-Id antibodies to anti-DNA antibodies could induce a transient suppression of anti-DNA antibody production in NZB/WF 1 mice (19), but failed in MRL/1 pr mice (20). Thus, elucidating the properties of anti-Id antibodies could be important not only for understanding the pathophysiological role of Id-anti-Id interaction in autoimmunity, but also for manipulating autoantibody production in autoimmune diseases (21). However, it has not yet been established whether human anti-Id autoantibodies recognize a private Id or a cross-reactive Id of autoantibodies. We also do not know if human anti-Id are directed against antigen-binding sites (paratope) or the framework region of antibody molecules.

In order to shed light upon the above-mentioned problems, we have studied the interaction between Id and anti-Id using human monoclonal anti-DNA antibodies and murine monoclonal anti-Id antibodies $(22,23)$ and demonstrated that there are heterogeneous populations of anti-Id antibodies to antiDNA antibodies in human (23a). In the present study, we demonstrate that anti-Id antibodies with different Id-recognizing properties occur in human SLE and healthy subjects, indicating that the Id network system regulates human self-tolerance.

\section{Methods}

Reagents. Calf thymus DNA was purchased from Worthington Biochemicals (Freehold, NJ). DNase 1 was from Sigma Chemical Co. (St. Louis, $\mathrm{MO}$ ) and polynucleotides and $\mathrm{S}_{1}$ nuclease from Miles Laboratories (St. Louis, MO). DNA obtained commercially was purified further as described previously (24) and used as double-stranded(ds)DNA or single-stranded(ss)DNA.

Sera and monoclonal antibodies. Sera were obtained from 40 female and 3 male patients with SLE, or 11 female and 14 male healthy subjects. Immunoglobulins (Ig) were precipitated twice with $33 \%$ saturated ammonium sulfate and isolated by DEAE-cellulose chromatography. Some were further prepared as $\mathrm{F}\left(\mathrm{ab}^{\prime}\right)_{2}$ fragments. Each sample was pretreated with DNase I (Sigma Chemical Co.) and absorbed with pooled human IgG- and IgM-coupled-Sepharose 4B before use. Some were then passed through DNA-coupled Sepharose 4B affinity column (25).

Human monoclonal IgM anti-ssDNA antibodies (O-81) or IgM anti-dsDNA antibodies (NE-1 and NE-13) were obtained from EBVtransformed B cell clones (26). Another IgM anti-dsDNA antibody (7F4) was from a human-human hybridoma using 6TG resistant B lymphoblastoid cell line GK-5 (a gift from Dr. Sato, National Institutes of health, Bethesda, MD) and lymphocytes from healthy subjects. Each anti-DNA antibody was purified using affinity chromatography of DNA-coupled Sepharose 4B (25). Murine IgG I $_{1}$ monoclonal anti-Id antibodies to 0-81 or NE-1 were produced from hybridomas (21) and designated D1E2 or 1F5, respectively. The anti-Id antibodies were 
purified twice using a DEAE-cellulose column and further prepared as $\mathrm{F}\left(\mathrm{ab}^{\prime}\right)_{2}$ fragments. The characteristics of these monoclonal antibodies are shown in Table $\mathbf{I}$.

Measurement of anti-DNA antibodies and anti-Id activity to antiDNA antibodies. Anti-DNA antibody activity was measured mainly with a modified solid-phase RIA as described in other papers (27).

Anti-Id antibodies were measured by direct binding to anti-DNA antibodies using solid phase RIA. Each well was coated with $100 \mu \mathrm{l}$ of affinity-purified anti-DNA antibodies (O-81, NE-1, NE-13, or 7F4) or with pooled human IgM ( 2 to $5 \mu \mathrm{g} / \mathrm{ml})$ in $0.15 \mathrm{M}$ PBS, pH 7.2, and was incubated for $2 \mathrm{~h}$ at room temperature. After being washed in PBS containing $0.2 \% \mathrm{BSA}$ and $0.05 \%$ Tween 20 (washing buffer), the wells were covered with $1 \%$ BSA in PBS for $60 \mathrm{~min}$ at room temperature. Then, 1:500 diluted test samples were added to the wells and incubated at $37^{\circ} \mathrm{C}$ for $90 \mathrm{~min}$. After being washed, ${ }^{125} \mathrm{I}$-labeled anti-human $\gamma$ rabbit $\operatorname{IgG} \mathrm{F}\left(\mathrm{ab}^{\prime}\right)_{2}$ was added and incubated for an additional $2 \mathrm{~h}$ at room temperature. Bound radioactivity was determined using a $\gamma$ counter.

Anti-Id activity was also determined by showing that antibodies could block the binding of monoclonal anti-DNA antibodies to monoclonal anti-Id antibodies. First, $100 \mu \mathrm{l}$ of 1:20 diluted sample, which was pretreated with DNase I followed by the absorption of pooled IgM-coupled Sepharose before use, was mixed and settled with $100 \mu \mathrm{l}$ $\left(2 \times 10^{4} \mathrm{cpm}\right)$ of ${ }^{125} \mathrm{I}$-labeled anti-DNA antibody (O-81 or NE-1) in a plastic tube at room temperature. After $90 \mathrm{~min}$ incubation, $100 \mu \mathrm{l}$ of 1:500 diluted anti-Id antibodies (D1E2 or 1F5) was added and incubated for $90 \mathrm{~min} .200 \mu \mathrm{l}$ of anti-mouse $\gamma$ rabbit Ig F( $\left.\mathrm{ab}^{\prime}\right)_{2}$ were added and tubes were incubated for another $90 \mathrm{~min}$. After centrifugation, the radioactivity of the precipitates was measured in a $\gamma$-counter.

Isoelectric focusing and immunoblotting. Flat bed isoelectric focusing (IEF) was performed in an apparatus (Pharmacia Fine Chemicals, Piscataway, $\mathrm{NJ})$ at $4^{\circ} \mathrm{C} .5 \%$ polyacrylamide gels $(10 \times 20 \times 0.1)$ were made using $0.1 \%$ Tween 20 . 20- $\mu$ l samples of IgG were applied to the gel surface using Whatman No. 1 filter paper wicks, and focused at constant power $(30 \mathrm{~W})$ to a maximum of $3,000 \mathrm{~V}$ at $4^{\circ} \mathrm{C}$ for $2 \mathrm{~h}$. The $\mathrm{pH}$ gradient was measured using a flat membrane $\mathrm{pH}$ electrode or IEF calibration kit. The focused gel was carefully removed from the plate, placed in a gel transfer holder, and blotted electrophoretically on to a nitrocellulose membrane at $(1.45 \mu \mathrm{m})$ in transfer buffer $(0.7 \%$ acetic acid) for $30 \mathrm{~min}$ at $30 \mathrm{~V}$ and $30 \mathrm{~min}$ at $150 \mathrm{~V}$. After blotting, free binding sites on the nitrocellulose membrane were blocked by incubating for $1 \mathrm{~h}$ at $37^{\circ} \mathrm{C}$ on a rocker platform in $100 \mathrm{ml}$ of $1 \% \mathrm{BSA}$ in PBS containing $0.1 \%$ Tween 20 . The membranes were then rinsed three times with PBS containing $1 \%$ BSA and $0.1 \%$ Tween 20 (washing buffer) and then overlaid with ${ }^{125}$ I-human monoclonal anti-DNA antibodies, $\mathrm{O}-81$ or NE-1, or IgM for $90 \mathrm{~min}$ at room temperature with rocking. Lastly the membranes were rinsed overnight with several changes of washing buffer of the rocker at room temperature. The

Table I. Characteristics of Monoclonal Antibodies

\begin{tabular}{|c|c|c|c|}
\hline Antibodies & Source & Ig class & Specificity \\
\hline O-81 & $\begin{array}{l}\text { EBV-transformed B } \\
\text { cell clone }\end{array}$ & Human IgM & $\begin{array}{l}\text { Anti-ssDNA, } \\
\text { poly(dT) }\end{array}$ \\
\hline NE-1 & $\begin{array}{l}\text { EBV-transformed B } \\
\text { cell clone }\end{array}$ & Human IgM & Anti-ds/ssDNA \\
\hline NE-13 & $\begin{array}{l}\text { EBV-transformed B } \\
\text { cell clone }\end{array}$ & Human IgM & Anti-ds/ssDNA \\
\hline $7 F 4$ & $\begin{array}{l}\text { Human-Human } \\
\text { hybridoma }\end{array}$ & Human IgM & Anti-ds/ssDNA \\
\hline D1E2 & Murine hybridoma & Murine IgGl & $\begin{array}{l}\text { Anti-idiotypic Ab to } \\
\text { O-81 }\end{array}$ \\
\hline 1F5 & Murine hybridoma & Murine IgGl & $\begin{array}{l}\text { Anti-idiotypic Ab to } \\
\text { NE-1 }\end{array}$ \\
\hline
\end{tabular}

membranes were dried and exposed to Kodak X-Omat X-ray film at $-70^{\circ} \mathrm{C}$.

Competitive inhibition RIA. Competitive inhibition was determined by measuring inhibition of direct binding of anti-Id antibodies to monoclonal anti-DNA antibodies using a solid-phase RIA. Prior to inhibition, each sample was diluted to the middle point of the maximum binding to $0-81, \mathrm{NE}-1$, or 7F4. A mixture of the test sample and $50 \mu \mathrm{l}$ of inhibitors at varying dilutions was incubated for $90 \mathrm{~min}$ in wells coated with monoclonal anti-DNA antibodies at $37^{\circ} \mathrm{C}$. Results were expressed as percentage inhibition of anti-DNA antibody-binding activity.

\section{Results}

Evidence for the direct binding ability of human anti-Id antibodies to anti-DNA antibodies. Anti-Id autoantibodies in human were first tested by solid phase RIA after sequential absorption of the sample on columns containing pooled human IgG and IgM. Fig. 1 shows the binding of sera from active and inactive SLE and healthy subjects. About $60 \%$ of sera from subjects with inactive SLE show specific binding to human monoclonal anti-DNA antibodies. $20-30 \%$ of active SLE and control sera also showed the binding ability to O-81 and NE-1. Binding of these antibodies is specific for Id of monoclonal anti-DNA antibodies because the binding to O-81, NE-1, NE-13, or 7F4 is apparently higher than those to irrelevant antibodies IgM. The specificity of binding is also demonstrated in Fig. 2, where preincubation with DIE2 or IF5

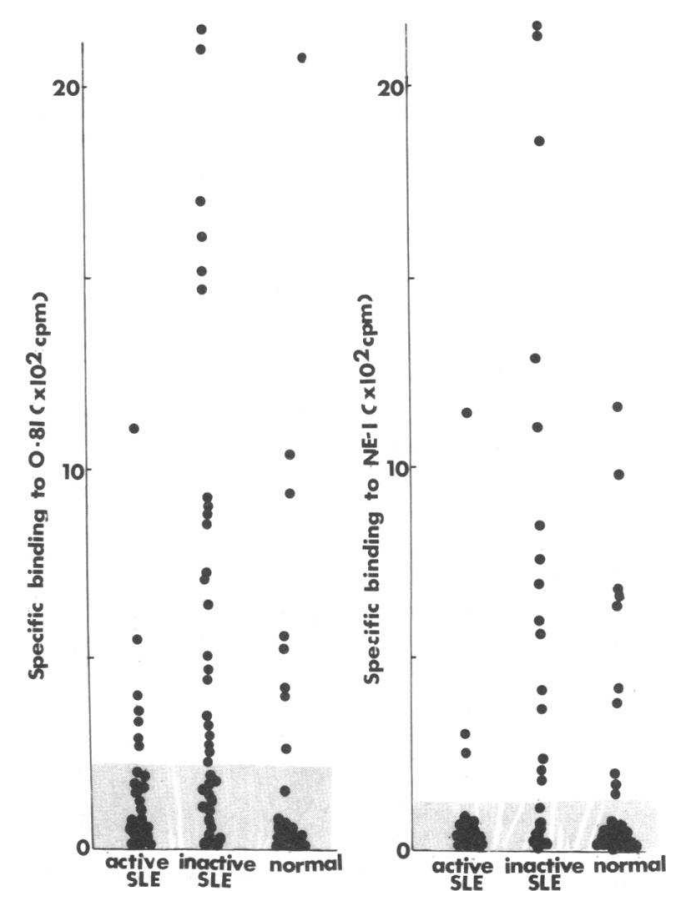

Figure 1. Direct binding of human anti-Id antibodies to human monoclonal anti-DNA antibodies, O-81 (left) and NE-1 (right). Each sample was incubated in wells coated with O-81, NE-1 or pooled IgM for $90 \mathrm{~min}$ at room temperature. After being washed with buffer, the ability to bind to ${ }^{125}$ I-labeled anti-human rabbit Ig F $\left(\mathrm{ab}^{\prime}\right)_{2}$ was determined as described in Methods. Data are expressed as total binding to $0-81$ or NE-1 minus that of IgM (the range of direct binding to IgM is $\sim 200-1,000 \mathrm{cpm}$ ). The specific binding to Id determinants was regarded as positive by the inhibition of the samples' binding to Id-coated wells by the coexistence of free Id(O-81 or NE-1). 


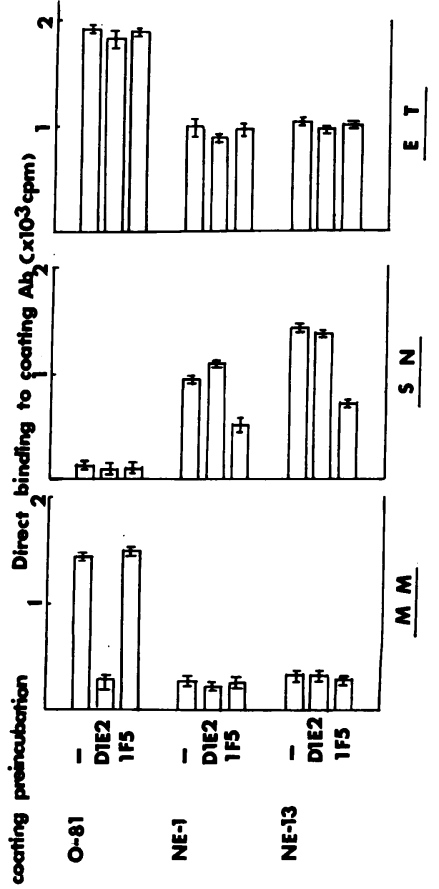

Figure 2. Direct binding of human anti-Id antibodies to human monoclonal anti-DNA antibodies. Wells coated with NE-1, NE-1 3 or O-81 were first incubated with 1:500 diluted D1E2 or 1F5 (murine monoclonal anti-Id antibodies) at $37^{\circ} \mathrm{C}$ for $90 \mathrm{~min}$, washed with the buffer several times and then incubated with 1:100 diluted human sera at room temperature for $90 \mathrm{~min}$. The following procedure was the same as described in Fig. 1. M.M. and S.N. are inactive SLE. E.T. is a healthy male subject.

blocked subsequent binding of M.M. and S.N. sera with O-81 or NE-1. Anti-Id antibodies in sera were separated by isoelectric focusing, transferred to a nitrocellulose membrane, and tested for binding to ${ }^{125}$ I-labeled 0-81 or NE-1 and to human IgM. As shown in Fig. 3, anti-Id antibodies were detected at a range of pH 5.5 to 7.0. The binding of ${ }^{125}$ I-NE-1 was almost completely blocked by unlabeled NE-1 or DNA but not by O-81 or IgM (data not shown). Analogous results were ob- tained with anti-O-81 antibodies, whose binding to ${ }^{125} \mathrm{I}-\mathrm{O}-81$ was blocked only by unlabeled 0-81 (data not shown).

Inhibition of antigen-antibody reactions by anti-Id antibodies. Next, we showed that small amounts of anti-Id autoantibodies blocked the binding of DNA by human monoclonal anti-DNA antibodies. Samples were pretreated with DNase 1 and IgM-coupled Sepharose and passed through DNA Sepharose to remove any antibodies in the sera. 10 of 14 sera that had shown binding to anti-DNA antibodies markedly inhibited the interaction of ${ }^{125} \mathrm{I}-\mathrm{O}-81$ with ssDNA (Fig. 4) but not ${ }^{125}$ I-NE-1-binding to dsDNA (Table II). Some inhibited the binding of O-81 to ssDNA as well as that of NE-1 to dsDNA. Comparable amounts of some anti-Id positive sera did not show such inhibition when tested with each reagents (Fig. 4).

Comparison of the incidence of anti-Id antibodies determined by different assays. We expected that anti-Id autoantibodies would also block the binding of monoclonal anti-DNA antibodies to murine monoclonal anti-Id antibodies. Indeed, we found a correlation between inhibition of ${ }^{125} \mathrm{I}-\mathrm{O}-81$ or ${ }^{125} \mathrm{I}$ NE-1 to murine monoclonal anti-Id, D1E2, or IF5 and direct binding in most of sera. The samples that strongly inhibited the reaction, had also high binding capacity (Fig. 5). Some, however, bound to $\mathrm{O}-81$ or NE-1, but failed to block binding of O-81 to D1E2 or NE-1 to 1F5.

The binding specificity of anti-Id autoantibodies. T.K. and T.N. both reacted with $0-81$ Id determinants as confirmed by direct binding assays. However, only T.K. blocked DNA-binding by O-81 (Table II). T.K. but not T.N. inhibited the interaction between ${ }^{125} \mathrm{I}-\mathrm{O}-81$ and D1E2. Thus, the binding specificity of anti-Id autoantibodies differs. We used a competitive inhibition solid-phase RIA to study further the human autoantibody specificity. Inhibition produced by IgG and an $F\left(a b^{\prime}\right)_{2}$ fragment that had bound directly, was measured by diluting each to a concentration that produced half-maximal

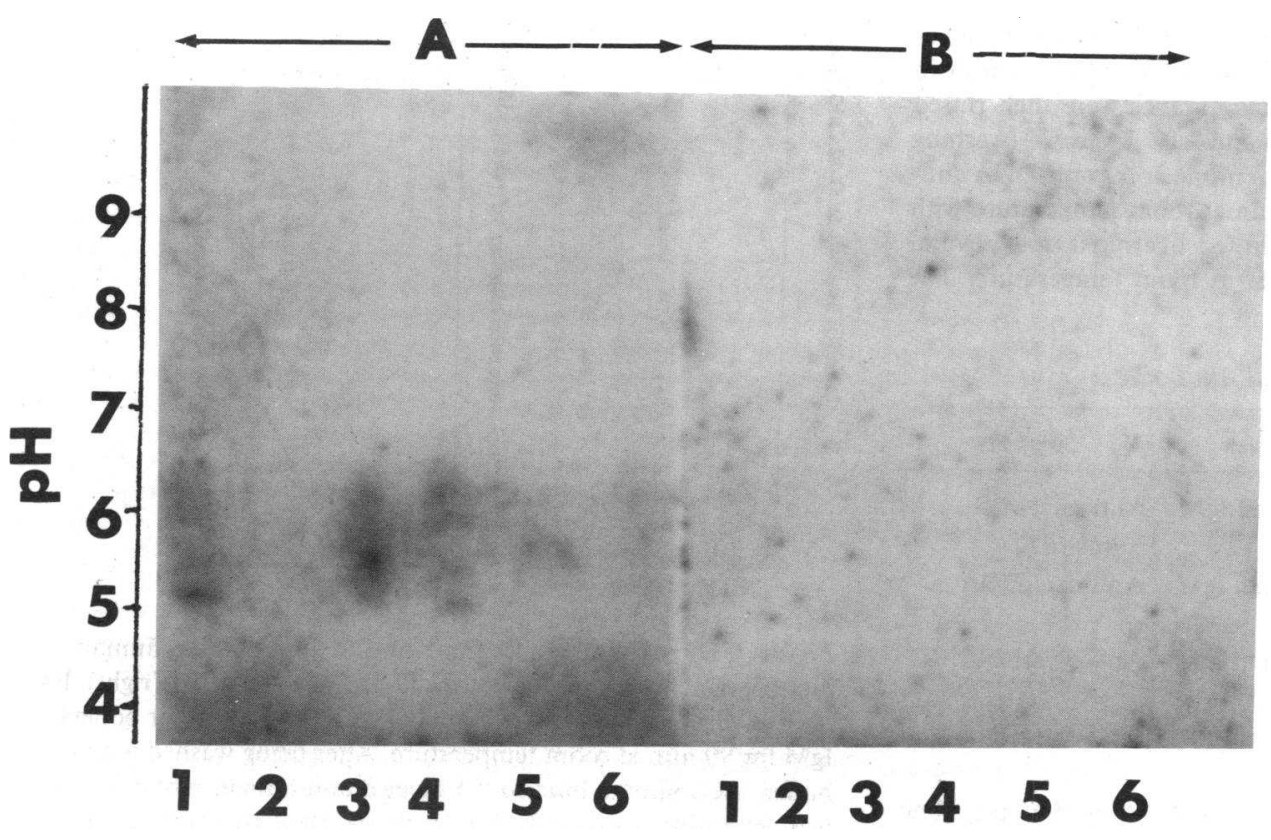

Samples
Figure 3. Analysis of anti-Id antibodies by isoelectric focusing and immunoblotting. Inactive SLE samples were focused, blotted to a nitrocellulose membrane, and finally incubated with ${ }^{125} \mathrm{I}-\mathrm{NE}-1(A)$ and ${ }^{125} \mathrm{I}$ $\operatorname{IgM}(B)$ as described in Methods. 


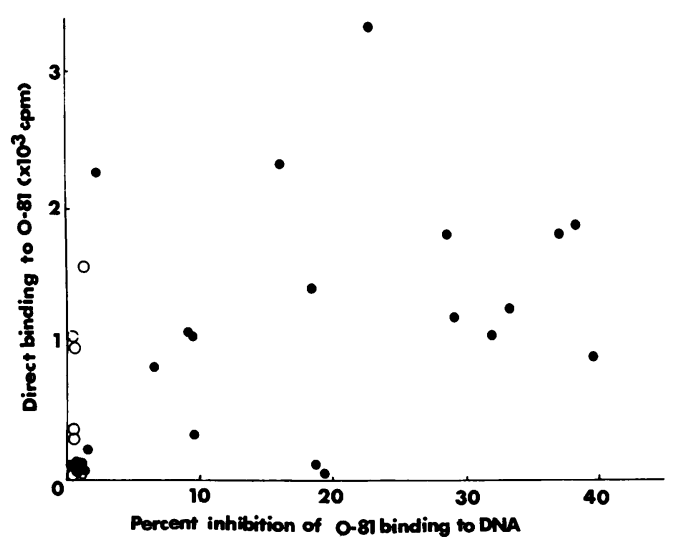

Figure 4. Interaction between the direct binding ability to anti-DNA antibodies by human anti-Id antibodies and the ability to inhibit binding of O-81 to DNA by human anti-Id antibodies. ${ }^{125}$ I-labeled $0-81\left(2 \times 10^{4} \mathrm{cpm}\right)$ was incubated with 1:100 diluted samples in well coated with $0-81$ for $90 \mathrm{~min}$ at room temperature and then counted with a gamma counter. Data are expressed as the percentage inhibition of uninhibited binding of ${ }^{125} \mathrm{I}-\mathrm{O}-81(\sim 10,000 \mathrm{cpm})$. The direct binding ability was assessed by an analogous method described in Fig. 1. •, Inactive SLE sera; O, normal sera.

binding before being mixed with inhibitors. The results of the competitive inhibition studies were shown in Fig. 6 and the tested samples were from patients with inactive SLE, (T.K., N.S., S.S., N.O., N.S., N.T., and S.U.) and from healthy subjects (K.A., O.K., T.N., O.O., E.T., and J.K.). The binding of T.K. to O-81 was apparently inhibited by ssDNA, O-81, and D1E2 but not by, NE-1 and 1F5. N.S.- or S.S.-binding to O-81 was also blocked by ssDNA or O-81, but not by anti-Id(D1E2), NE-1, or pooled IgM. However, comparable amounts of DNA or murine monoclonal anti-Id antibodies failed to suppress the interaction between humoral anti-DNA antibodies and serum anti-Id antibodies from most healthy subjects. We noted that the binding of O-81 to the wells was inhibited by the addition of NE-1, NE-13, 7F4, as well as O-81. The binding of all anti-DNA antibodies to wells was also inhibited by NE-1 but pooled IgM was not. To determine what sites were recognized by anti-Id antibodies in T.K. or S.U. sera, various types of polynucleotides were tested for their ability to inhibit the reaction between anti-DNA antibodies and anti-Id antibodies. This was compared with the results obtained using murine

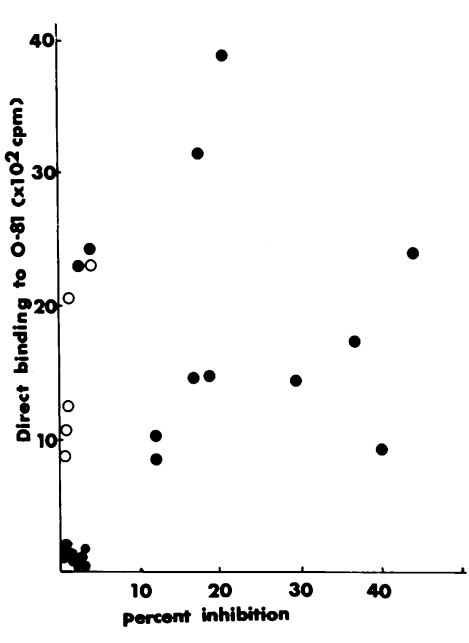

Figure 5. Comparison of the direct binding ability to O-81 with the ability to inhibit $\mathrm{O}-81$ binding to D1E2. $200 \mu \mathrm{l}\left(4 \times 10^{4}\right.$ cpm) of ${ }^{125} \mathrm{I}-\mathrm{O}-81\left(2 \times 10^{4}\right.$ cpm) were preincubated with $200 \mu$ l of 1:200 diluted sample for $90 \mathrm{~min}$ at room temperature and then binding to D1E2 was measured to by the doubleantibody method described in Methods. The percentage inhibition was calculated using binding in the presence of $0.2 \%$-BSA-PBS as $100 \%(\sim 5,000 \mathrm{cpm})$. The direct binding ability was determined as described in Fig. 1. $\bullet$, inactive SLE sera; $\circ$, normal sera.

monoclonal anti-Id antibodies (Fig. 7). It was demonstrated that T.K. antibodies and D1E2 had similar specificities. The effects of polynucleotides on the interaction between NE-1 and S.U. were also analogous to those seen with 1F5.

\section{Discussion}

This paper described the binding properties of anti-Id autoantibodies to human anti-DNA antibodies. We used human monoclonal anti-DNA antibodies derived from SLE and healthy subjects because the Id-anti-Id has been difficult to study using polyclonal anti-DNA antibodies (15-17). O-81 reacts with ssDNA but not with dsDNA, while, NE-1, NE-13, and 7F4 bind not only to ssDNA, but also to dsDNA, RNA, or cardiolipin (27). The specificity of NE-1 differs somewhat from the antigen-binding specificity of NE-13 or 7F4. The murine monoclonal anti-Id antibodies D1E2 selectively bind to Id of O-81 and 1F5 recognizes Id determinants in paratope of NE-1 and NE-13 but not that in O-81. D1E2- or 1F5-binding to the corresponding Id was inhibited by the coexistence of DNA antigens (23). When D1E2 or 1F5 coupled with KLH were administered to mice, $\mathrm{Ab} 3$ with anti-DNA activity could be elicited in their sera (data not shown). Thus, both anti-Id

Table II. Comparison of the Incidence of Anti-Id Antibodies Determined by Different Assays

\begin{tabular}{|c|c|c|c|c|c|c|c|c|}
\hline \multirow[b]{2}{*}{ Patient } & \multirow[b]{2}{*}{ Disease } & \multicolumn{3}{|c|}{ Direct binding to* } & \multicolumn{2}{|c|}{ Percent inhibition of ${ }^{\ddagger}$} & \multicolumn{2}{|c|}{ Percent inhibition of ${ }^{\ddagger}$} \\
\hline & & $0-81$ & NE-1 & IgM & O-81-ssDNA & NE-1-dsDNA & O-81-D1E2 & NE-1-1F5 \\
\hline T.K. & Inactive SLE & 2,803 & 443 & 625 & 17.6 & 1.5 & 42.9 & 0 \\
\hline T.N. & Healthy & 2,514 & 1,754 & 576 & 1.4 & 0 & 0.5 & 0 \\
\hline N.S. & Inactive SLE & 1,346 & 372 & 428 & 30.4 & 0 & 14.9 & 0 \\
\hline M.M. & Inactive SLE & 3,855 & 2,392 & 772 & 21.9 & 20.0 & 18.9 & 11.5 \\
\hline T.S. & Active SLE & 576 & 674 & 645 & 0 & 0 & 0 & 0 \\
\hline
\end{tabular}

Each sample was measured for the anti-Id antibody activity by direct binding tests, inhibition tests to O-81-binding to ssDNA, NE-1-binding to dsDNA, and inhibition assays to O-81-binding to D1E2, NE-1-binding to 1F5 as described in Methods. * Total binding to each monoclonal anti-DNA antibody and pooled human IgM (counts per minute). ${ }^{\ddagger}$ The percent inhibition was calculated using binding in the presence of $0.2 \%$ BSA-PBS as $100 \%$ as Figs. 5 and 6. 
A
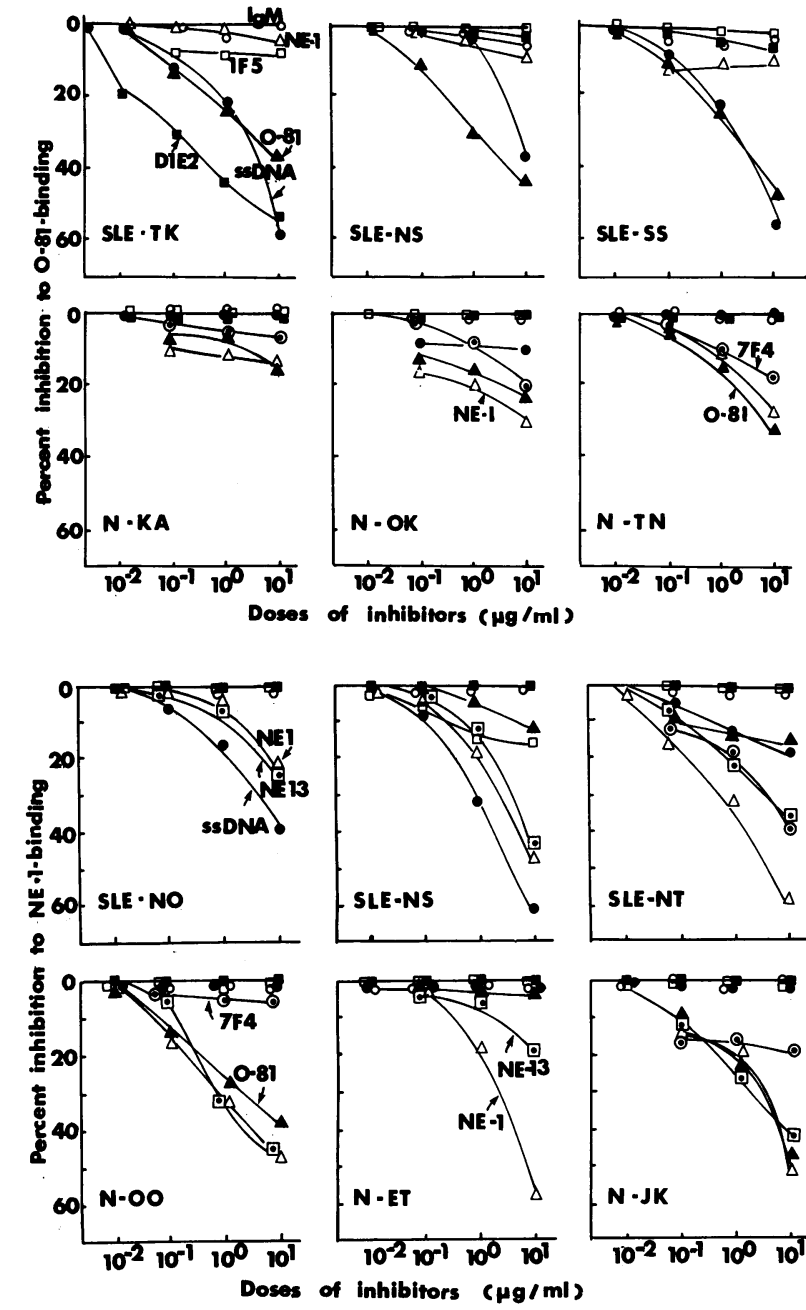

Figure 6. Inhibition of human anti-Id antibody-binding to O-81(A) or to NE-1(B) by DNA, human monoclonal anti-DNA antibodies or murine monoclonal anti-Id antibodies. Anti-Id positive samples were incubated with the indicated concentrations of free DNA ( $\bullet), 0-81$ $(\triangle)$, NE-1 $(\Delta), 7 F 4(\odot)$, pooled IgM (O), D1E2 (₫) or 1F5 (ם), in wells coated with $0-81(\mathrm{~A})$ or NE-1(B). The binding ability of the samples was determined as described in Methods. Data are expressed as the percentage inhibition of uninhibited binding $\left(1-3 \times 10^{3} \mathrm{cpm}\right)$. T.K., N.S., S.S., N.O., N.S. and N.T. were from SLE patients and K.A., O.K., T.N., O.O., E.T., and J.K. from normal subjects. S.S., J.N., N.T., and J.K. were used as $F\left(a b^{\prime}\right)_{2}$ fragments.

antibodies seem to behave almost as internal images of the antigens recognized by anti-DNA antibodies. The above mentioned data indicate that these monoclonal antibodies $(0-81$, NE-1, and NE-13) represent different kinds of Id markers of anti-DNA antibodies. Although we used human monoclonal anti-DNA antibodies, we have evidence that these Id occur in vivo because we have found anti-DNA antibodies with the same Id as O-81 or NE-1 in sera and on the surface of human lymphocytes (Takai, O., manuscript in preparation). Consequently, we feel that the system presented in this experiments represents the in vivo Id-anti-Id interaction.

The binding of serum anti-Id antibodies to human monoclonal anti-DNA antibodies is not due to antiallotypic activity as described in other paper (23a). Women's sera may contain a
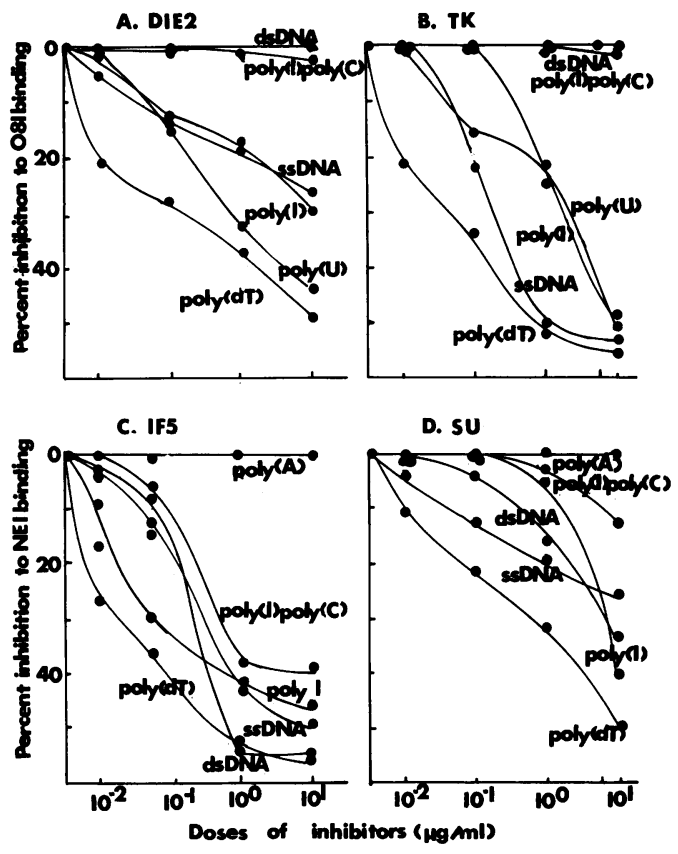

Figure 7. Comparison of murine and human anti-Id antibody-binding to anti-DNA antibodies. D1E2 or inactive SLE IgG(T.K.) was incubated with the indicated concentrations of free polynucleotides in wells coated with O-81. 1F5 or other inactive SLE IgG(S.U.) was also incubated with free antigens in wells coated with NE-1. The binding ability of the anti-Id antibodies was determined as Fig. 6.

broad spectrum of antiallotype antibodies. The antibodies from male normal subjects, however, showed similar property of anti-Id antibodies with that of female controls. In addition, the repeated preabsorption of the sera by pooled IgG- and IgM-coupled Sepharose did not change the level of total binding to $0-81$ or that to NE-1. This was also confirmed by Figs. 2 and 3.

The system used in this report allowed us to compare the Id determinants recognized by the anti-Id autoantibodies. It should be kept in mind that the assay was restricted to detect IgG type antibodies. The results suggest that there are at least two different specificities of anti-Id antibodies. One type was directed toward Id determinants in the antigen-binding sites of antibody molecules. An anti-Id, T.K. specifically bound to O-81, but never to other anti-DNA antibodies or pooled IgM. T.K. also blocked O-81-binding to DNA. Moreover, the binding of O-81 to T.K. could be blocked not only by ssDNA, but also by poly(dT), poly(I), poly(U), which preferentially bind to O-8 (23). T.K. has the same binding properties as D1E2, a murine monoclonal anti-Id antibody raised against $0-81$. Other anti-Id antibodies had similar reactivities to monoclonal anti-DNA antibodies (Figs. 5-7). These antibodies may belong to the categories of $A b 2 \beta$ or Ab $2 \gamma$ described by Bona (27). Another group also reacted with the anti-DNA antibodies. These sera, however, failed to block the binding of anti-DNA antibodies to DNA and 0-81- or NE-1-binding to these antibodies could not be blocked by DNA. In addition, comparable amounts of D1E2 or 1F5 failed to block the Id-anti-Id interaction of these sera. Thus, the anti-Id activity in this group seems to be directed towards the framework regions of anti-DNA antibodies, showing $\mathrm{Ab} 2 \alpha$ activity (27). It is interesting that 
O-81-binding to anti-Id antibodies in some sera was inhibited by NE-1, NE-13, 7F4, as well as O-81, but not by pooled IgM. Similar results were obtained with NE-1-, NE-13-, and 7F4binding. These indicate that anti-Id antibodies may recognize the Id determinants in the framework common among these anti-DNA antibodies.

Recently, anti-DNA antibodies have been shown to crossreact with cardiolipin, vimentin, and bacterial polysaccharides (28-32) and to share Id determinants with monoclonal antibodies reactive to Klebsiella and Escherichia coli (33-35). Anti-DNA, anti-gp 70, and other antibodies may constitute a network of idiotypically related antibodies in mice (36). Schwartz and his co-workers have demonstrated the presence of a parallel set of anti-DNA antibodies, which shared Id in the framework of anti-DNA antibodies but failed to bind DNA (36). Thus, there are mounting data that anti-DNA and related Id might occur in the association with bacterial or viral infection $(37,38)$. In this respect, it is interesting that all dominant Id systems are related to antibacterial antibodies (39). If we agree with these interaction, it is reasonable to speculate that naturally occurring idiotypes may induce the anti-Id antibodies to cross-reactive to anti-DNA antibodies (7). Considering above mentioned viewpoints, it should be noted that anti-Id antibodies with $\mathrm{Ab} 2 \alpha$ activity to anti-DNA antibodies were detected in healthy subjects. $\mathrm{Ab} 2 \alpha$ has been demonstrated to be able to function in a manner similar to $\mathrm{Ab} 2 \beta$ to suppress the specific immune response in vivo and in vitro (40-42). Diamond and co-workers speculated that $\mathrm{Ab} 2 \alpha$ to anti-DNA antibodies could regulate autoantibody production in vitro (43). Taken together, these results suggest that anti-Id antibodies (Ab $2 \alpha$ ) evoked by the stimulation of the parallel sets might work to regulate anti-DNA production on idiotypic network. This might result in maintaining the homeostasis of the immune response to self-components under normal circumstances. The Id regulatory mechanism may be broken during an acute episode in SLE, although we do not know yet about the factors to contribute to the breakdown of self-tolerance. In this condition, large amounts of anti-DNA autoantibodies occur in the circulation. Consequently, the paratopes of antiDNA antibodies might be antigenic and selectively activate the restricted clones that would have affinity to the antigen-binding sites (paratope) of anti-DNA antibodies. Then, the regulatory mechanism might operate via feedback control by the resulting anti-Id antibodies. This might be the reason why anti-Id antibodies directed against the antigen-binding sites of anti-DNA antibodies occurred in remission. We are currently studying whether or not these anti-Id autoantibodies are able to regulate anti-DNA production in humans.

The finding just mentioned may also have clinical importance. Treatment with anti-Id alters the formation of antiDNA antibodies, which clearly play an important role in the tissue damage seen in $\operatorname{SLE}(44,45)$. The sequential administration of anti-Id antibodies could suppress the total amounts of circulating autoantibodies to acetylcholine receptor (46) or to DNA (19). In humans, anti-Id antibodies effectively regulate already established spontaneously occurring autoantibodies in vitro $(42,47)$. We do not know if anti-Id antibodies with sharp specificities would induce efficient immunosuppression of all autoantibodies produced in autoimmune states (20). Our results, using monoclonal antibodies, suggested that a majoring of pathogenic autoantibodies share a small number of Id. This finding may permit a new therapeutic strategy.

\section{Acknowledgments}

We thank Miss M. Suzuki for preparing the manuscript.

This work was supported by a grant-in-aid for Scientific Research from the Ministry of Education, Science and Culture, and by a research grant for Autoimmune diseases from the Ministry of Health and Welfare, Japan.

\section{References}

1. Oudin, J., and M. Michel. 1969. Idiotypy of rabbit antibodies. Comparison of idiotypy of antibodies against Salmonella typhi with that of antibodies against other bacteria in the same rabbits, or against Salmonella typhi in various rabbits. J. Exp. Med. 130:595-617.

2. Kunkel, H. G., J. Agnello, F. G. Joslin, R. J. Winchester, and J. D. Capra. 1973. Cross-idiotypic specificity among monoclonal IgM proteins with anti- $\gamma$-globulin activity. J. Exp. Med. 137:331-342.

3. Jerne, N. K. 1974. Towards a network theory of the immune system. Ann. Immunol. (Paris). 125C:373-389.

4. Eichman, K., and K. Rajewsky. 1975. Induction of T and B cell immunity by anti-idiotypic antibody. Eur. J. Immunol. 5:661-666.

5. Bona, C., and W. E. Paul. 1979. Cellular basis of regulation of expression of idiotype. I. T-suppressor cells specific for MOPC 460 idiotype regulate the expression of cells secreting anti-TNP antibodies bearing 460 idiotype. J. Exp. Med. 149:592-600.

6. Theofilopoulos, A. N., and F. J. Dixon. 1982. Autoimmune diseases; immunopathogeneses. Am. J. Pathol. 108:321-330.

7. Cooke, A., P. M. Lydyard, and I. M. Roitt. 1983. Mechanism of autoimmunity: a role for cross-reactive idiotypes. Immunology Today. 4:170-175.

8. Zanetti, M. 1985. The idiotype network in autoimmune processes. Immunology Today. 6:299-302.

9. Marion, T. H., A. R. Lawton III, J. F. Kearney, and D. E. Briles. 1982. Anti-DNA antibodies in (NZB/NZW) F1 mice and clonally heterogenous, but the majority share a common idiotype. J. Immunol. 128:668-674.

10. Rauch, J., E. Murphy, B. Rogh, B. D. Stollar, and R. S. Schwartz. 1982. A high frequency idiotypic marker of anti-DNA autoantibodies in MRL/1/pr/lpr mice. J. Immunol. 129:236-241.

11. Zanetti, M., M. De Baets, and J. Rogers. 1983. High degree of idiotypic cross-reactivity among murine monoclonal antibodies to thyroglobulins. J. Immunol. 131:2452-2457.

12. Isenberg, D. A., Y. Schoenfeld, M. P. Madaio, J. Rauch, M. Reihclin, B. D. Stollar, and R. S. Schwartz. 1984. Anti-DNA antibody idiotypes in systemic lupus erythematosus. Lancet. ii:418-421.

13. Lymberi, P., G. Dighiero, T. Ternynck, and S. Avrameas. 1985. A high incidence of cross-reactive idiotypes among murine natural autoantibodies. Eur. J. Immunol. 15:702-707.

14. Monestier, M., A. Manheimer-Lory, B. Bellon, C. Painter, H. Dang, N. Talal, M. Zanetti, R. Schwartz, D. Pisetsky, R. Kuppers, N. Rose, J. Brochier, L. Klareskog, R. Holmdahl, B. Erlanger, F. Alt, and C. Bona. 1986. Shared idiotopes and restricted immunoglobulin variable region heavy chain genes characterize murine autoantibodies of various specificities. J. Clin. Invest. 78:753-759.

15. Abdou, N. I., H. Wall, H. B. Lindsley, J. F. Halsey, and T. Suzuki. 1981. Network theory in autoimmunity. In vitro suppression of serum anti-DNA antibody binding to DNA by anti-idiotypic antibody in systemic lupus erythematosus. J. Clin. Invest. 67:1297-1302.

16. Dwyer, D. S., R. J. Bradley, C. K. Urguart, and J. F. Kearney. 1983. Naturally occurring anti-idiotypic antibodies in myasthenia gravis patients. Nature (Lond.). 301:611-614.

17. Sikorska, H. A. 1986. Anti-thyroglobulin anti-idiotypic antibodies in sera of patients with Hashimoto's thyroiditis and Graves' disease. J. Immunol. 137:3786-3795.

18. Sasaki, T., T. Muryoi, O. Takai, E. Tamate, Y. Ono, Y. Koide, N. Ishida, and K. Yoshinaga. 1986. Selective elimination of anti-DNA antibody-producing cells by anti-idiotypic antibodies conjugated with neocarzinostatin. J. Clin. Invest. 77:1382-1384. 
19. Hahn, B. H., and F. M. Ebling. 1984. Suppression of murine lupus nephritis by administration of anti-idiotypic antibody to antiDNA. J. Immunol. 132:187-190.

20. Teitelbaum, D., J. Rauch, B. D. Stollar, and R. S. Schwartz. 1984. In vivo effects of antibodies against a high frequency idiotype of anti-DNA antibodies in MRL mice. J. Immunol. 132:1282-1285.

21. Tamate, E., T. Sasaki, T. Muryoi, O. Takai, K. Otani, K. Tada, and K. Yoshinaga. 1986. Expression of idiotype on the surface of human B cells producing anti-DNA antibody. J. Immunol. 136:12411246.

22. Sasaki, T., T. Muryoi, Y. Sekiguchi, E. Tamate, K. Yoshinaga, and Y. Kitagawa. 1985. Monoclonal human anti-DNA antibodies from EB virus-transformed lymphocytes of systemic lupus erythematosus (SE) patients. J. Clin. Immunol. 5:246-253.

23. Muryoi, T., T. Sasaki, E. Tamate, O. Takai, N. Harata, and $K$. Yoshinaga. 1987. Antigen inhibition of the interaction between murine monoclonal anti-idiotypic antibodies and human anti-DNA antibodies. Tohoku J. Exp. Med. 152:264-267.

23a. Muryoi, T., T. Sasaki, N. Harata, O. Takai, E. Tamate, and K. Yoshinaga. 1988. Heterogeneity of anti-idiotypic antibodies to antiDNA antibodies in humans. Clin. Exp. Immunol. 71:67-71.

24. Sasaki, T. Passive hemagglutination and hemolysis test for anti-DNA antibody. Methods Enzymol. 84:291-295.

25. Kitagawa, Y., and T. Sasaki. 1987. Specific purification of monoclonal anti-DNA antibodies from culture medium using a DNA-coupled Sepharose 4B affinity column. J. Immunol. Methods. 96:7-10.

26. Sasaki, T., F. Endo, Y. Sekiguchi, M. Mikami, K. Tada, N. Ishida, and K. Yoshinaga. 1984. Establishment of human monoclonal anti-DNA producing cell lines. J. Immunol. Methods. 72:157-165.

27. Bona, C. A., S. Finley, S. Waters, and H. G. Kunkel. 1982. Anti-immunoglobulin antibodies. III. Properties of sequential antiidiotypic antibodies to heterologous anti- $\gamma$ globulins. Detection of reactivity of anti-idiotype antibodies with epitopes of $\mathrm{Fc}$ fragments (homobodies) and with epitopes and idiotopes (epibodies). J. Exp. Med. 156:986-999.

28. Shoenfeld, Y., S. C. Hsu-Lin, J. E. Gabriels, L. E. Silberstein, B. C. Furie, B. Furie, B. D. Stollar, and R. S. Schwartz. 1982. Production of autoantibodies by human-human hybridomas. J. Clin. Invest. 70:205-208

29. Andre-Schwartz, J., S. K. Datta, Y. Shoenfeld, D. A. Isenberg, B. D. Stollar, and R. S. Schwartz. 1984. Binding of cytoskeletal proteins by monoclonal anti-DNA lupus autoantibodies. Clin. Immunol. Immunopathol. 31:261-271.

30. Jacob, L., F. Tron, J. F. Bach, and D. Louvard. 1984. A Monoclonal anti-DNA antibody also binds to cell-surface protein(s). Proc. Natl. Acad. Sci. USA. 81:3843-3845.

31. Faaber, P., P. J. A. Capel, G. P. M. Rijike, G. Vierwinden, L. B. A. van de Putte, and L. H. M. Berden. 1984. Cross reactivity of anti-DNA antibodies with proteoglycans. Clin. Exp. Immunol. 55:502-508.

32. Carroll, P., D. Stafford, R. S. Schwartz, and B. D. Stollar. 1985.
Murine monoclonal anti-DNA autoantibodies bind to endogenous bacteria. J. Immunol. 135:1086-1090.

33. Naparstek, Y., D. Duggan, A. Schattner, M. P. Madaio, F. Govi, B. Fragione, B. D. Stollar, E. A. Kabat, and R. S. Schwartz. 1985. Immunochemical similarities between monoclonal antibacterial Waldenström's macroglobulins and monoclonal anti-DNA lupus autoantibodies. J. Exp. Med. 161:1525-1538.

34. Koffler, R., D. J. Noonan, D. E. Levy, M. C. Wilson, N. P. H. Møller, F. J. Dixon, and A. N. Theofilopoulos. 1985. Genetic elements used for a murine lupus anti-DNA autoantibody are closely related to those for antibodies to exogenous antigens. J. Exp. Med. 161:805-815.

35. Diamond, B., and M. Scharff. 1984. Somatic mutation of the T15 heavy chain fives rise to an antibody with auto-antibody specificity. Proc. Natl. Acad. Sci. USA. 81:5841-5844.

36. Migliorini, P., B. Ardman, J. Kaburaki, and R. S. Schwartz. 1987. Parallel sets of autoantibodies in MRL-1 pr/1 pr mice. An antiDNA, anti-smRNP, anti-gp70 network. J. Exp. Med. 165:483-499.

37. Datta, S. K., Y. Naparstek and R. S. Schwartz. 1986. In vitro production of an anti-DNA idiotype by lymphocytes of normal subjects and patients with systemic lupus erythematosus. Clin. Immunol. Immunopathol. 38:302-318.

38. Yamamoto, H., M. Nonaka, and D. H. Katz. 1979. Suppression of hapten-specific delayed-type hypersensitivity responses in mice by idiotype-specific suppressor $\mathrm{T}$ cells after administration of antiidiotypic antibodies. J. Exp. Med. 150:818-829.

39. Bottomly, K. 1984. 1984: All idiotypes are equal, but some are more equal than others. Immunol. Rev. 79:45-61.

40. Kelsoe, G., M. Reth, and K. Rajewsky. 1980. Control of idiotope expression by monoclonal anti-idiotype antibodies. Immunol. Rev. 52:75-92.

41. Kelsoe, G., M. Reth, and K. Rajewsky. 1981. Control of idiotope expression by monoclonal anti-idiotope and idiotope-bearing antibody. Eur. J. Immunol. 11:418-423.

42. Tan, E. M., P. H. Schur, and R. I. Carr. 1966. Deoxyribonucleic acid (DNA) and antibody to DNA in the serum of patients with systemic lupus erythematosus. J. Clin. Invest. 45:1732-1740.

43. Epstein, A., M. Greenberg, B. Diamond, and A. I. Grayzel. 1987. Suppression of anti-DNA antibody synthesis in vitro by a crossreactive antiidiotypic antibody. J. Clin. Invest. 79:997-1000.

44. Koffler, D., P. H. Schur, and H. G. Kunkel. 1967. Immunological studies concerning the nephritis of systemic lupus erythematosus. J. Exp. Med. 126:607-624.

45. Tojo, T., and F. J. Frio. 1966. Lupus nephritis: Varying complement-fixing properties of immunoglobulin and antibodies to antigens of cell muclei. Science (Wash. DC). 16:904-905.

46. Agius, M. A., and D. P. Richman. 1986. Suppression of development of experimental autoimmune myasthenia gravis with isogeneic monoclonal anti-idiotypic antibody. J. Immunol. 137:2195-2198.

47. Koopman, W. J., R. E. Schrohenloher, J. C. Barton, and E. C. Greenbaf. 1983. Suppression of an in vitro monoclonal rheumatoid factor synthesis by antiidiotypic antibody. Target cells and molecular requirements. J. Clin. Invest. 72:1410-1419. 